\title{
Especialização e especialidade
}

$\mathrm{E}$ m 2009, o Conselho Federal de Fisioterapia e Terapia Ocupacional (COFFITO) criou uma comissão de profissionais ligados a diferentes especialidades reconhecidas por este a fim de normatizar as especialidades da Fisioterapia. O objetivo final foi estabelecer critérios para postulação de títulos de especialista profissional, necessários para o crescimento e amadurecimento da profissão.

Os trabalhos foram desenvolvidos com o método denominado Developing a Currículum (DACUM), ferramenta de abordagem qualitativa, reconhecida em nível mundial para a análise de profissões e para o desenvolvimento de perfis profissionais configurando-se em um grupo focal. $\mathrm{O}$ workshop DACUM teve a duração de cinco dias, no período de 28 de agosto a 1 de setembro de 2009, e permitiu o levantamento de funções, habilidades, atitudes e conhecimentos das diferentes especialidades, culminando com a Resolução COFFITO no 377, de 11 de junho de 2010 (DOU no 133 , Seção 1, em 14/7/2010, páginas 921/923), que dispõe sobre as normas e procedimentos para o registro de títulos de especialidade profissional em Fisioterapia.

Após divugada a Resolução COFFITO no 377 deu-se início ao processo de viabilização das provas. Novamente, as associações conveniadas com o COFFITO foram chamadas para determinar as diretrizes curriculares de cada especialidade, visando à elaboração das provas de conhecimento. $\mathrm{O}$ referido exame visa a verificar o conhecimento do profissional na especialidade por ele requerida, e foi aplicado pela primeira vez dia 22 de abril de 2012.

Os candidatos também foram avaliados pela prova de títulos, que é uma avaliação objetiva de documentação comprobatória que visa valorar a experiência prática e o aperfeiçoamento do profissional na especialidade, bem como a experiência prática e o aperfeiçoamento deste em área afim da especialidade por ele requerida.

As provas foram aplicadas com vista ao título de especialista em diversas áreas: Fisioterapia Dermatofuncional, Fisioterapia em Acupuntura,
Fisioterapia em Osteopatia, Fisioterapia em Quiropraxia, Fisioterapia Respiratória, Fisioterapia na Saúde da Mulher, Fisioterapia em Terapia Intensiva, Fisioterapia Esportiva, Fisioterapia do Trabalho, Fisioterapia Neurofuncional, Fisioterapia Oncológica e Fisioterapia Traumato-Ortopédica.

Contudo, mediante divulgação do trabalho desenvolvido e regras já estabelecidas, muitos profissionais ainda têm dúvidas em relação aos cursos de pós-graduação - denominados de especialização - e a especialidade profissional, e neste contexto faremos uma breve exposição sobre o tema.

Após o término da graduação, o profissional poderá dar seguimento aos estudos por meio dos cursos de pós-graduação denominados no Brasil de Lato Sensu ou Stricto Sensu.

Os cursos de Pós-Graduação Lato Sensu têm caráter de educação continuada, voltados ao aprimoramento acadêmico/profissional, com carga horária mínima de 360 horas, oferecidos por instituição de ensino superior (IES) ou por instituição especialmente credenciada pelo poder público para atuar nesse nível educacional. São também denominados "cursos de especialização", e têm por objetivo o domínio científico e técnico de uma determinada e limitada área do saber ou da profissão, podendo ser eventuais, e concedem certificado, sendo que atualmente no Brasil também existem cursos a distância (Resolução $\mathrm{n}^{\circ} 1$, de 3/4/2001) que, oferecidos por instituições credenciadas incluem, necessariamente, provas presenciais e defesa presencial de monografia ou trabalho de conclusão de curso.

A pós-graduação Stricto Sensu é definida como curso regular que se superpõe à graduação, é sistematicamente organizado, com o objetivo de desenvolver e aprofundar a formação científica ou cultural adquirida no âmbito da graduação (Parecer no 977/1965 e Parecer no 77/1969 do $\mathrm{CFE}$ ). Esses cursos são de natureza acadêmica, bem como de pesquisa, e conduzem à obtenção de grau acadêmico. Compreendem dois níveis independentes de formação que concedem diplomas de Mestrado ou Doutorado. 
É importante destacar que os títulos conferidos pelos "cursos de especialização" apresentam caráter acadêmico; entretanto, atualmente a designação "especialista em Fisioterapia" no âmbito profissional está condicionada à aprovação em exame de conhecimento e prova de títulos, que atestam a experiência profissional e conhecimento direcionado à especialidade requerida.

A Associação Brasileira de Fisioterapia Dermatofuncional (ABRAFIDEF), é uma associação profissional, legalmente constituída, a qual, através do convênio com o COFFITO, representa os profissionais que atuam na área. $\mathrm{A}$ ABRAFIDEF participou ativamente de todo o processo de normatização da especialidade que culminou com a aplicação das provas de título de especialista profissional.

Dra. Bernadete Pita Presidente da ABRAFIDEF

Profa. Dra. Elaine Guirro VICE-PRESIDENTE dA ABRAFIDEF 